\title{
Long Tail Strings: Impact of the Dalkon Shield 40 Years Later
}

\author{
Clare L. Roepke1, Eric A. Schaff ${ }^{2}$ \\ ${ }^{1}$ Lacusc Medical Center, Los Angeles, USA \\ ${ }^{2}$ Philadelphia Women's Center, Philadelphia, USA \\ Email: eschaff@aol.com
}

Received 20 September 2014; revised 15 October 2014; accepted 8 November 2014

Copyright (C) 2014 by authors and Scientific Research Publishing Inc.

This work is licensed under the Creative Commons Attribution International License (CC BY). http://creativecommons.org/licenses/by/4.0/

(c) (i) Open Access

\begin{abstract}
Intrauterine devices (IUDs) are the most effective, reversible and longest acting birth control method. They require no effort for compliance and avoid systemic synthetic hormones. Evidencebased effectiveness and safety studies have demonstrated IUDs rival sterilization. IUDs low cost make them the most popular method worldwide. Despite these benefits, IUDs have minimal market penetration in the United States where they are expensive, disparaged by an older generation of physicians, and withheld from teenagers, nulliparous women, and women not in mutually monogamous relationships, i.e., those who would most benefit. This article reviews the nearly forgotten history of the IUD that resulted in broadening the Food and Drug Administration's oversight of medical devices, brought needed transparency to physicians' conflicts of interests, uncovered a corporate scandal with a whistleblower that led to a major pharmaceutical bankruptcy, and involved 327,000 women (though only 195,000 met strict criteria for claims) in the largest US personal injury case.
\end{abstract}

\section{Keywords}

IUD, Dalkon Shield, Review, Infertility, History, Scandal, Birth Control

\section{Introduction}

The United States leads developing countries in the number of teenage pregnancies each year. Nearly half of all pregnancies in US women are unintended, and four in ten of these end in abortion [1] [2]. From a public health perspective, it is important to promote the safest, least expensive, and most effective birth control method to combat such high numbers. But, US women desiring an intrauterine device (IUD) are often denied, accepting less effective birth control methods that have high discontinuation rates that can lead to unintended pregnancy.

Consumers and physicians have been undereducated and therefore not promoting IUDs. In the late 1980s, a 
survey of obstetrician-gynecologists and family physicians in San Diego County, California, found that $40 \%$ were not recommending the copper IUD to anyone, primarily for fear of medical liability [3]. More recently, in a 2002 survey of American College of Obstetricians and Gynecologists (ACOG) members, with a response rate of $50 \%$, found that $79 \%$ had inserted 10 or fewer IUDs in the past year [4]. Surveys of US women in 2006 and in 2008 found that most young women were unaware of IUDs in general [5] [6].

\section{Brief History of Modern Contraception in the US}

While there was some interest in intrauterine devices (IUDs) in the early 1900s and again in the late 1930s, it wasn't until the late 1950s that IUDs came to market in the US. The major technological advance that made this possible was the invention of plastics (nylon, Dacron, polyethylene and polypropylene). Plastics were inert, lightweight, and flexible with "memory" and, therefore, could be molded to be inserted without the need for cervical dilation. They were approved for meat packing though not tested in humans. "Plastics" were changing the world as the 1967 award-winning movie The Graduate memorialized. In addition, there were steady improvements in antibiotics that made the possibility of uterine infections associated with IUDs less concerning.

The 1960s was also a dynamic and turbulent period in American history. The world's population had doubled to one billion people since the 1930s raising anxiety about worldwide shortages and famine. The civil rights movement, led by African Americans against racism, culminated with the 1964 landmark civil rights legislation that extended voting rights and officially ended racial segregation in public institutions. This movement led others to question the status quo and made it easier for women and other minorities in the 1970s to demand equal access to education and employment opportunities, directly confronting sexual and other racial discrimination.

The birth control pill, approved by the Food and Drug Administration (FDA) as a contraceptive in 1961, heralded another significant advance for women's economic and social independence by separating sex from reproduction. Reflecting these changing times, the Supreme Court decision in Griswold v. Connecticut (1965) acknowledged that the government had no interest in denying contraception to married couples and, in Eisenstadt v. Baird (1972), to unmarried couples. The option of abortion was not readily available for an unintended pregnancy until it was legalized with the 1973 Supreme Court Roe v. Wade decision. Women needed effective methods of contraception to avoid an unintended pregnancy and public health advocates were eager to use these new contraceptive technologies to stem “overpopulation”.

During the 1960s and 70s, condoms evoked much ambivalence. They were banned in advertisements on national television by the American National Association of Broadcasters until 1979 [7]. Not until the 1980s, when the human immunodeficiency virus (HIV) was discovered did condoms become an integral component of family planning programs and sales increased dramatically around the world for HIV prevention.

IUDs and oral contraceptives cost little to manufacture and yet could reap huge profits from these new local and global markets. Two polyethylene plastic IUDs were approved in 1966, the Lippes Loop ${ }^{\circledR}$ and the Safe-tcoil $^{\circledR}$. Copper IUDs were introduced in Chile in the late 1960s. By 1970, 12 million women around the world and 3 million in the US [8] were using IUDs. The sexual revolution had arrived.

Unfortunately, the initial contraceptive pill approved by the FDA in 1961 had high doses of both synthetic estrogen and progesterone. While highly effective, there were increasing reports over the next decade of serious adverse events of thromboembolism, myocardial infarctions, and strokes. (The latter two will be confounded by cigarette smoking and high blood pressure.) More common side effects, such as nausea, vomiting, and bloating, led to high discontinuation rates and forced many women to seek safer alternatives. By 1970, the US Senate, under the direction of Senator Gaylord Nelson, a Democrat from Wisconsin, held hearings on the growing dangers of the birth control pill highlighting the need for the consumer to know. One significant outcome of these hearings was the requirement of pharmaceutical industry to place side effects and adverse event reports in medication package inserts.

\section{History of the Dalkon Shield}

In 1966, Robert Israel and Hugh Davis from Johns Hopkins University reported their study to explain the possible mechanism of action of IUDs. From histology of uteri post hysterectomy, they found that IUD users had chronic non-infectious inflammation in the endometrium that was not present in non-IUD users [9]. Davis, already recognized as an expert in the field of family planning, proposed that an IUD with greater surface area and, consequently, more endometrial contact would have an increased inflammatory response and, therefore, im- 
proved effectiveness [10]. He and an engineer colleague, Irwin Lerner, designed an IUD that was circular with a thin membrane in the inside of the circle to increase surface contact with the endometrium. They also wanted to avoid the high expulsion rate of current IUDs, so they designed five small plastic fins on either side of the circular device which would serve to secure the IUD in place in the endometrium and prevent it from falling out. IUDs required a tail string which consisted of a monofilament polypropylene string that would project out the cervix to facilitate removal. With the larger surface area of this new IUD and the increased resistance to removal from the fins, came the need for a more durable tail string that would not break compared with the tail strings of other IUDs. Davis and Learner identified a string called Supramid [11], a cable-type suture material made of hundreds of fine inner nylon fibers encased by a smooth nylon outer shell that was used to repair tears of tendons to bones of horses.

Davis, Lerner, and their attorney, Cohn, started a company called the Dalkon Corporation to promote this new IUD, called the Dalkon Shield. (The origin of the name, Dalkon, likely came from a juxtaposition of parts of all of the initial owners' names, although this was denied by Davis. It was called a shield because it resembled a policeman's badge [12].)

In 1968-1969, Davis studied his new Dalkon Shield IUD in 640 inner city women from Baltimore over a 12-month period [13]. This involved 3,549 women-months of experience. Using life-table analysis, he reported a pregnancy rate of $1.1 \%$, an expulsion rate of $2.3 \%$ and a net retention rate of $94 \%$. Expulsion and removals for bleeding complications were reported as "greatly reduced” and their product appeared very promising.

With the addition of one more investor, the four stock holders realized that their fledgling Dalkon Corporation needed the backing of a major pharmaceutical company with a sizable sales force to reach a large consumer audience to be profitable. In 1971, the Dalkon Corporation was purchased by the A. H. Robins Company, (one of the top 500 gross revenue companies in the US called the Fortune 500) with well-known products such as Chapstick $^{\circledR}$ and Robitussin ${ }^{\circledR}$. Though they had no prior experience in women's health, Robins purchased the Dalkon Corporation for \$750,000, beating a competitive bid from the Upjohn Company. Davis’ share was $\$ 242,812$ plus a $\$ 20,000 / y e a r$ consulting fee and future royalties that will eventually total approximately $\$ 725,000$ by 1974 [14]. With the results of Davis’ one-year study, Robins rushed to market using an aggressive marketing campaign that included direct advertising to the consumer with information highlighting the benefits of the Dalkon Shield. They targeted not only experienced gynecologists but less experienced family physicians to maximize market penetration. In the next three years, Robins succeeded in capturing 60\% of the US IUD market, i.e., 2.2 million Dalkon Shield IUDs sold in the US with an additional 1.7 million sold abroad [15]. The cost of the Dalkon Shield to Robins was $\$ 0.35$ which they then sold for $\$ 4.35$ to physicians who, in turn, charged around $\$ 12$ to patients [16].

In the early 1970s, the Food and Drug Administration (FDA) did not regulate medical devices, just medications. But, there were growing consumer concerns because medical devices were increasingly prevalent, complex, and risky, such as contact lens, suture threads, dental prostheses, pace makers, and even artificial heart valves. While the FDA was not involved with medical devices, the public mistakenly believed that there was some oversight and regulation of these products.

In hindsight, there were problems with the Dalkon Shield. It was said to take 10 times more force to insert a Dalkon Shield compared with a Lippes Loop and, consequently, it caused significant pain on insertion. Removals were also difficult. If a concerned clinician contacted Robins about the difficulty with their product, the medical team recommended a regimen of Demerol $50 \mathrm{mg}$, atropine $0.5 \mathrm{mg}$ and a local anesthesia using lidocaine for insertion and removal [17] though this was not part of the routine instructions.

After the Dalkon Shield's introduction in 1971, case reports of medical problems began to surface. Robins spin on pelvic infections were that they were likely relapses of prior infections, poor insertion technique on the part of the physician, or poor hygiene on the part of the woman. After the first year on the market and with no explanation, Robins recommended the use of spermicidal agents for the first several months after insertion [18] which was likely their response to an unexpected increase in the number of pregnancies being reported to them.

At the time, it was generally accepted in the medical community that if pregnancy occurred with an IUD in place, the pregnancy would "gently push the IUD to the side", and therefore should be left in place. There were also no recommendations for routine screening for sexually transmitted infections (STIs) or for use of condoms if at risk for STIs. Chlamydia, the major bacteria responsible for pelvic infections today (and likely then), was unknown until the 1980s.

The Robins Company remained silent about the increased infection rates until 1974 when studies in journals 
were about to be published about pelvic infections, septic abortions and deaths associated with the Dalkon Shield [19]. In was also found that its multifilament tail string encased in nylon, chosen originally for its strength, served as a wick for vaginal fluid and bacteria to access inside the uterus [20] bypassing antibacterial actions of the cervical mucus and providing the mechanism for the higher infection rate noted. In 1975, the FDA formally cited the Supramid $^{\circledR}$ tail string as a hazard [21].

Pregnancies with an IUD in place led to spontaneous, often late term abortion in $40 \%$ - $60 \%$ of cases, often requiring transfusion, hospitalization, and intravenous antibiotics. Later studies would show, from 1972-1974, deaths from spontaneous abortion were 50 times greater in women who continued their pregnancy with the IUD in place compared with those who did not [22].

In 1974, against the recommendations of their in-house lawyer, Roger Tuttle, Robins under increasing pressure, stopped selling the Dalkon Shield in the US, though they added that there was "no reason to believe at this time that physicians should remove the Dalkon Shields from patients now wearing [them]". They did not recall devices in use and continued to market the Shield overseas for an additional 10 months. With mounting medical evidence, Robins also recommended that the Shield be removed if the woman became pregnant which now had become the standard of medical care [23].

Robins' actions were too little and too late. Later reports will confirm that the Dalkon Shield had already caused tens if not hundreds of thousands of adverse events including pelvic infections [24] [25], 242 septic abortions [26], ectopic pregnancies, hysterectomies, and at least 18 deaths (a number that was likely higher given the lack about Dalkon Shield use in developing countries).

With the Dalkon Shield no longer on the market since 1974, there were few lawsuits initially and media attention was waning. In the mid 1970s, Robins was in an advantageous position with experienced lawyers, all the company's product information, and unlimited resources. If needed, they could purposely prolong litigation that a plaintiff's small law firm would likely be unable to sustain. But, this was about to change. A few plaintiff law firms used a new controversial strategy for their time, i.e., they purchased full page newspaper and magazine ads across the US, searching for victims of the Dalkon Shield. This caught media attention and led to a dramatic increase in plaintiffs which, in turn, attracted larger law firms which had more resources for mounting prolonged litigation. These law firms learned quickly the benefits of working together to share an increasing amount of data from pre-trial discovery, the procedural device that requires the opposing party to disclose information. Court cases were consolidated by judges so as not to tie up courts. Robins, faced with a much more organized opponent throughout the US, had to settle cases which only added to the plaintiff attorneys' resolve.

With persistent plaintiff attorney demands, discovery found damaging information in Robin's early documents that raised ethical issues about both Davis' conduct and performance of his Dalkon Shield study. Davis never acknowledged his financial conflict of interest from his continued royalties from the sale of the Dalkon Shield to his University nor in his writings in support of his IUD. He lied under oath to the Senate during the "Pill Hearings" in 1970 when he denied having personal financial interest in IUDs [27]. His original study, the basis for Robins marketing, was flawed. The Shield's pregnancy rate was considerably higher than what he published in 1970. From article submission, i.e., one month after the end of the 12-month study ended, to the time of publication four months later, the pregnancy rate had increased from $1.2 \%$ to between 3 and $5 \%$ depending on using absolute numbers or survival analysis [28]. The 12-month study had neither enough participants nor was long enough in duration to determine an accurate pregnancy or adverse events rate, as the average women was enrolled for a little over 5 months and few women studied for 12 months. Women who dropped out of the study, an important subgroup worth noting because of likely problems, were not included in the results. Davis had also recommended a back-up method of birth control for the first three months post-insertion but failed to mention this critical information in his report. As discovery documents showed, despite these known problems, Davis and the Robins Company remained silent except to continue to market the $1 \%$ failure rate of this "superior contraception”.

Discovery documents also showed that the Dalkon Shield that Davis tested in 1968-1969 and reported on in 1970 was not the Shield that went to market in 1971, i.e., the "improved" Shield had never been tested. From his study, Davis identified problems with his product and worked with Robins to correct the flaws prior to marketing the Shield. The Shield's membrane was thinned to make it smaller and easier to fold in half to help with insertion. Additional barium sulphate was added to the plastic to make the device more opaque on $\mathrm{x}$-ray so that the device would be better visualized by radiography. The tips of the fins were rounded to make them less piercing of the endometrium. A scaled down Shield by a couple of millimeters was introduced as a second device target- 
ing an additional population of nulliparous women. Copper sulphate was added to the plastic because new studies indicated that copper increased the effectiveness of IUDs. (In 1971, a new IUD, the Copper 7, was ruled by the FDA to be a drug and not a device because copper ions were released that contributed to the device's effectiveness. In an effort to evade oversight by the FDA and the labeling of the Dalkon Shield as a medication, Robins lied to the FDA and claimed that the copper sulphate added, did not have any contraceptive benefit but only helped with imaging [29].)

By 1976, two years after the Dalkon Shield was off the market and much more was now known about the damage it caused, the FDA amended the Food, Drug and Cosmetic Act to require extensive testing and their approval before marketing any medical devices, including IUDs. In 1990 and 1992, Congress enacted additional laws that strengthened post-market surveillance of devices by requiring reporting of serious device-related injuries or deaths not only by manufacturers but by hospitals, health care providers, and patients. Violations could be misdemeanors or felonies with significant criminal implications and fines [30].

Increasing Dalkon Shield lawsuits in the last half of the 1970s threatened loses of over \$450 million for Robins. After their in-house lawyer, Roger Tuttle, lost their first case in 1975, Robins hired an experienced outside law firm to aggressively defend their position. As part of their legal defense of the higher than expected infection rate, these lawyers attempted to place the blame on poor technique by the physician and the woman's high risk sexual behaviors by attacking the moral character of the women who used the Shield hoping to stem more lawsuits. Plaintiff women were asked intimate questions about their sexual practices, their hygiene, and their personal relationships. Such personal scrutiny ruined some of these women's family lives, their reputations, and their careers [31].

Infertility was being reported in previous Dalkon Shield users who had experienced prior pelvic infections and tubal scarring. The individual psychological and economic costs were high due to the strained or failed personal relationships from the infertility and chronic pelvic pain. This was compounded by the realization that many of these problems could have been prevented if Robins had not withheld information from the public and had moved quickly to remedy the situation.

In 1980, with a pending CBS 60 Minutes [32] expose of the Dalkon Shield's high infection rate and continued deaths in current user, Robins sent a letter to almost 200,000 physicians recommending the removal of the Dalkon Shield from women who were still wearing them six years after they were off the market. Robins also acknowledged a causal relationship between the Shield and physical injuries reported by its users. Finally, four years later, in 1984, and under increasing legal pressure with lawsuits totaling \$12 billion, Robins announced a multimillion dollar program that included full-page newspaper and magazine ads that warned women of the risks of the Dalkon Shield and offered to pay for its removal from women who were still wearing them [33].

\section{Cover-Up Exposed}

Lawsuits continued. In 1984, Minnesota Judge Miles Lord, while overseeing 21 Dalkon Shield cases against Robins, was concerned about reports that Robins executives had suppressed, lost or destroyed internal documents and had known that their device was defective [34]. He demanded more early documents under rules of discovery. Robins claimed they didn’t exist or were no longer available. Robins' lawyers retaliated by accusing Lord of not being impartial and eventually were able to remove Judge Lord from Dalkon cases [35].

Of note, it wasn't until the late 1970s, that federal and state laws were passed that prohibited an employer in private industry to retaliate against employees for reporting internal violations, i.e., whistleblowing [36]. In 1984, the original in-house Robin's lawyer, Roger Tuttle, who had left the company 10 years earlier, was now a law professor at Oral Roberts Law School in Oklahoma. He had been following the Dalkon Shield lawsuits in Minnesota and decided to come forward with additional information about his earlier employer. Tuttle confirmed, for the first time, that there was an organized cover-up by Robins' executives. He and others had been ordered to destroy documents in the early 1970s [37]. Before Robin's current lawyers were able to cast suspicions on Tuttle's character, Tuttle produced highly incriminating copies of documents that he had made before he had destroyed the originals.

Ten years after the product was off the market, the corporate cover-up was finally fully exposed. In one internal document dated June 11, 1970 by Fred Clark, Robin's medical director, he wrote that Davis' study had a pregnancy rate closer to $2.3 \%$ and not $1.1 \%$. It became evident that Robins had also known from the beginning that the tail strings could wick vaginal fluid and bacteria into the uterus that could lead to pelvic infections. 
When a Robins' quality control supervisory persisted in recommending changes in the tail string, he was fired. Another letter dated June 23, 1972, Dr. Thad Earl, who was then Robins' leading consultant on the Dalkon Shield, said that leaving a Dalkon Shield in place after pregnancy could result in septic abortion. It was also known that the outer nylon sheath of the tail string deteriorated in water over time with recommendations that the IUD be replaced every two years. In 1972, there were reports of "large numbers are breaking [string]". Instead, in 1972, Robins, concerned about competition from other IUDs, ignored this recommendation and changed its label to read that the device could be used for " 5 years or longer". There were also internal documents found that confirmed discussion that the nylon ends of the tail strings could have been heat-sealed to avoid the wicking affect, but these recommendations were ignored by management [38].

\section{Bankruptcy of A. H. Robins Company}

Exposing the cover-up was the final blow for A. H. Robins Company's defense strategy. The statute of limitations, i.e., the time that an injured party must start a lawsuit after an injury, which is typically within $2-3$ years depending on the state, should have expired for Dalkon Shield users and denied additional women from filing claims. The legal exception when the statute of limitation does not apply, is when the manufacturer's misrepresentations or concealment of information prevented consumers from discovering pertinent information. As the cover-up was exposed, the legal exception applied, and more women filed lawsuits. In the end, more than 327,000 women filed lawsuits [39] though this was decreased to 195,000 claims by court ordered protocol making it still one of the largest personal injury litigation in the history of the US.

Bankruptcy is intended for companies without adequate funding to meet their liabilities. Robins bankruptcy and reorganization was controversial for at the time of the filing, it was still financially sound and its assets were sufficient to cover the known liabilities from the Dalkon Shield cases pending. A bankruptcy with reorganization would protect the Companies remaining assets and prevent women with yet unknown problems such as infertility from being able to file a future claim.

Reorganization occurred and a $\$ 2.5$ billion Trust Fund was set up to pay all women claimants, and the value of the Company in excess of the Fund went back to shareholders. With future liabilities no longer a concern, the multinational Robins' corporation's stock prices increased four-fold [40] and, in 1989, they were able to sell the company to the American Home Products (later to become Wyeth) for \$3 billion with Robins' owners clearing $\$ 385$ million tax free [41].

Women who were injured were not going to have their day in court. 99,400 of the 195,000 eligible women chose the simplest options, a quick payoff of $\$ 725$. 150,000 of 195,000 cases were settled without involvement of counsel [42]. Most women in the large class action suit were paid less than \$1000 [43], a sum that did not adequately compensate those injured.

\section{Dalkon Shield Fall-Out}

In the mid and late 1970s, multiple studies confirmed the Dalkon Shield's strong association with pelvic inflammatory disease [44] [45], spontaneous abortion [46], ectopic pregnancy, and infertility [47] [48]. These studies led to recommendations that IUDs should be avoided in nulliparous women, teenagers, and populations at increased risk for PID [49].

Initial tactics of the Robins Company's lawyers to blame insertion technique and women's risky behaviors for infection as the cause of the Shield's problems antagonized and alienated both physicians and consumers. Ethical problems resulting from Davis' non-disclosed financial conflicts of interest with the Dalkon Shield, misrepresentations of erroneous data, and lying under oath to the US Senate from an academic physician at a major institution must have brought embarrassment to the medical profession. (Over the years, Davis continued to stand by his design. He retired from Johns Hopkins in 1982 and died in 1996 [50].) Overwhelmed by the mounting medical evidence against IUDs, physician and consumers were unwilling to use them, a prevailing sentiment that continues today.

Pharmaceutical companies witnessed how one IUD caused billions of dollars in liabilities and the bankruptcy of a major pharmaceutical company. They also realized that IUDs were not as profitable as their less controversial oral contraceptive product lines [51]. As such, from 1983-1988 there were no IUDs on the market in the United States [52]. It was not until 1984, after significant premarket evaluation did the FDA approve that the copper T IUD Paragard ${ }^{\circledR}$ though it was not introduced into practice until 1989. In 2000, the levonorgestrel-IUD 
Mirena ${ }^{\circledR}$ was approved. Both Paragard ${ }^{\circledR}$ and Mirena ${ }^{\circledR}$ were designed to avoid Dalkon Shield problems, i.e., small, flexible and with polyethylene monofilament strings. The US marketing of these two IUDS has been tentative, as noted by their costs to the consumer of $\$ 350$ - 550. In contrast, in 2005, the cost of the copper T IUD from the United States Agency for International Development (USAID), the federal government agency that advances US foreign policy objectives by supporting global health, was \$1.77 [53].

\section{Comeback of the IUD (at Least the Science)}

Evidence-based studies from the 1980s to the present on IUDs, without the Dalkon Shield's Supramid ${ }^{\circledR}$ tail $^{\text {' }}$ string, were dramatically different. For example, a post-Dalkon Shield multicenter case-control study of 615 women with ectopic pregnancies and 34 [53] controls found that women who had never used an IUD were as likely to have an ectopic pregnancy as women who had used one, though STIs did play a role [54]. In addition, since IUDs prevent most pregnancies, IUD users had a lower risk of ectopic pregnancy than women who do not use any contraception [55].

A 1988 report re-analyzed data from the 1974 Women's Health Study that had initially found the association between PID and IUDs, in particular, the Dalkon Shield. The new analysis found that when a history of gonorrhea and the number of recent sexual partners were controlled, women with one sexual partner, married and cohabitating had no significant increase risk of PID [56] [57] and these findings were later confirmed in a systematic meta-analysis [58]. Also reassuring, is the decreasing prevalence of PID in countries with increasing use of IUDs [59]. Current IUDs may decrease the risk for PID due to biocidal affects of copper [60] [61] and the thickening of cervical mucus preventing ascending infection when progesterone is imbedded in the IUD [62]. The high infection rate due to the wicking effect and deterioration of the Dalkon Shield's multifilament nylon tail string, has not been seen in modern IUDs with monofilament polypropylene tail strings [63].

A major concern was the association of IUDs and subsequent infertility, the primary reason to withhold this method from women who have not completed their childbearing, i.e., nulliparous and teenage women. Multiple studies, including a 2008 systematic meta-analysis, concluded that the risk of subsequent infertility from IUDs was minimal in nulliparous women when STIs and the number of sexual partners were controlled [64]-[66]. Not only do IUDs not cause infertility, but the ability to get pregnant returns rapidly after IUD removal [67].

When the Dalkon Shield was introduced in 1971, there was 1) no recommendation for routine STI screening [68]; 2) no selection criteria that would have excluded women at high risk for STI; 3) no recommendations to use condoms if at risk for STI; 4) no counseling for symptoms of early infection; 5) no recommendations for early antibiotic treatment; and 6) no recommendations to remove the IUD with a pelvic infection. Now, there are sensitive and noninvasive tests for sexually transmitted infections, such as nucleic acid amplification urine testing for Chlamydia and gonorrhea, that make screening much easier and greatly improve our ability to diagnose asymptomatic infections [69].

Science has come a long way. The American College of Obstetricians and Gynecologists [70] [71], the World Health Organization [72], and the US FDA [73] support IUD use in nulliparous women and teenagers who desire long-term pregnancy prevention (as long as there is no evidence of pelvic infection at the time of insertion).

\section{Conclusions}

The Dalkon Shield story started over 40 years ago. It was marketed for a brief three years but its aftermath continues today. It took a great deal of research to determine why this IUD caused injury and death. It took many injured women, persevering lawyers and a whistleblower to uncover the corporate scandal. In the end, it was an American tragedy of corporate greed and cover-up, blind consumer faith, government ineffectiveness, and embarrassment for the medical profession. Two million women in the US (and an additional 1.7 million women in 80 countries worldwide, of which we have little information) were hapless victims. Tens to hundreds of thousands of women suffered and almost 200,000 women were part of one of the largest liability litigation cases in the US.

Because of the Dalkon Shield, FDA policies changed to incorporate approval of medical devices which strengthened consumer protection. Universities, research review boards, and peer-reviewed journals strengthened transparency of scholars' conflicts of interest and research methodologies. Major pharmaceutical companies withdrew from marketing the IUD in the US for fear of liability and women remain uninformed about modern IUD benefits. An older generation of clinicians, who are now in a position of leadership and who lived through the Dalkon 
Shield scandal, are unmoved by current evidence-based medicine demonstrating that the modern IUD is, as Davis once called it, a "superior contraceptive".

\section{References}

[1] Spinelli, A., Talamanca, I.F. and Lauria, L. (2000) Patterns of Contraceptive Use in 5 European Countries. American Journal of Public Health, 90, 1403-1408. http://dx.doi.org/10.2105/AJPH.90.9.1403

[2] Finer, L.B. and Henshaw, S.K. (2006) Disparities in Rates of Unintended Pregnancy in the United States, 1994 and 2001. Perspectives on Sexual and Reproductive Health, 38, 90-96. http://dx.doi.org/10.1363/3809006

[3] Kooiker, C.H. and Scutchfield, F.D. (1990) Barriers to Prescribing the Copper T380A Intrauterine Device by Physicians. Western Journal of Medicine, 153, 279-282.

[4] Stanwood, N.L., Garrett, J.M. and Konrad, T.R. (2002) Obstetrician-Gynecologists and the Intrauterine Device: A Survey of Attitudes and Practice. Obstetrics and Gynecology, 99, 275-280. http://dx.doi.org/10.1016/S0029-7844(01)01726-4

[5] Stanwood, N.L. and Bradley, K.A. (2006) Young Pregnant Women's Knowledge of Modern Intrauterine Devices. Obstetrics and Gynecology, 108, 1417-1422. http://dx.doi.org/10.1097/01.AOG.0000245447.56585.a0

[6] Whitaker, A.K., Johnson, L.M., Harwood, B., Chiappetta, L., Creinin, M.D. and Gold, M.A. (2008) Adolescent and Young Adult Women's Knowledge of and Attitudes toward the Intrauterine Device. Contraception, 78, 211-217. http://dx.doi.org/10.1016/j.contraception.2008.04.119

[7] Collier, A. (2007) The Humble Little Condom: A History. Prometheus Books, Amherst, New York, 273-274, 285.

[8] Davis, H.J. (1972) Intrauterine Contraceptive Devices: Present Status and Future Prospects. American Journal of Obstetrics Gynecology, 114, 134-151.

[9] Israel, R. and Davis, H.J. (1966) Effect of Intrauterine Contraceptive Devices on the Endometrium. JAMA, 195, 764-768. http://dx.doi.org/10.1001/jama.1966.03100090098021

[10] Davis, H.J. and Lesinski, J. (1970) Mechanism of Action of Intrauterine Contraceptives in Women. Obstetrics and Gynecology, 36, 350-358.

[11] Supramid (2009). http://www.supramid.com/homeinfo.htm

[12] Mintz, M. (1985) At Any Cost: Corporate Greed, Women and the Dalkon Shield. Pantheon Books, New York. At 27.

[13] Davis, H.J. (1970) The Shield Intrauterine Device. A Superior Modern Contraceptive. American Journal of Obstetrics and Gynecology, 106, 455-456.

[14] See Mintz, Supra Note 64-65, 176-177.

[15] Hicks, K.M. (1994) Surviving the Dalkon Shield: Women v. the Pharmaceutical Industry. Teachers College Press, New York. At 43.

[16] Hawkins, M.F. (1997) Unshielded: The Human Cost of the Dalkon Shield. University of Toronto Press, Toronto, Buffalo, London. At 17.

[17] See Mintz, Supra Note 99-100.

[18] Perry, S. and Dawson, J. (1985) Nightmare: Women and the Dalkon Shield. MacMillan Publishing Company, New York. At 75.

[19] Christian, C.D. (1974) Maternal Deaths Associated with an Intrauterine Device. American Journal of Obstetrics and Gynecology, 119, 441-444.

[20] Tatum, H.J., Schmidt, F.H., Phillips, D., McCarty, M. and O’Leary, W.M. (1975) The Dalkon Shield Controversy, Structural and Bacteriological Studies of IUD Tails. Journal of the American Medical Association, 231, 711-717. http://dx.doi.org/10.1001/jama.1975.03240190015009

[21] See Mintz, Supra Note 147.

[22] Cates, W., Ory, H.W., Rochat, R.W. and Tyler, Z.C.W. (1976) The Intrauterine Device and Deaths from Spontaneous Abortion. The New England Journal of Medicine, 295, 1155-1159. http://dx.doi.org/10.1056/NEJM197611182952102

[23] See Mintz, Supra Note 162-167.

[24] Lee, N.C., Rubin, G.L., Ory, H.W. and Burkman, R.T. (1983) Type of Intrauterine Device and the Risk of Pelvic Inflammatory Disease. Obstetrics and Gynecology, 62, 1-6.

[25] Burkman, R.T. (1981) Association between Intrauterine Device and Pelvic Inflammatory Disease. Obstetrics and Gynecology, 57, 269-276.

[26] Tatum, H.J. (1983) Milestones in Intrauterine Device Development. Fertility and Sterility, 39, 141-143. 
[27] Bloss, R., Corneli, J., Moon, C. and Tomsich, L. (2010) The Dalkon Shield. http://www1.umn.edu/scitech/dalkfina.htm

[28] See Perry and Dawson, Supra Note 36.

[29] Ibid at 133-134.

[30] Staff Manual Guide (2010) Chapter 53, Postmarketing Surveillance and Epidemiology: Human Drugs http://www.fda.gov/Drugs/GuidanceComplianceRegulatoryInformation/Surveillance/ucm129115.htm

[31] See Hawkins, Supra Note 30.

[32] “Dalkon Shield” CBS 60 Minutes. April 12, 1981.

[33] See Mintz, Supra Note 208-209, 235-238.

[34] Ibid at 267.

[35] See Hawkins, Supra Note 39.

[36] Ravishankar, L. (2010) Encouraging Internal Whistleblowing in Organizations. http://www.scu.edu/ethics/publications/submitted/whistleblowing.html

[37] See Mintz, Supra Note 227.

[38] Ibid at 149-152.

[39] See Hicks, Supra Note 6.

[40] Ibid at 10.

[41] Sobol, R.B. (1991) Bending the Law: The Story of the Dalkon Shield Bankruptcy. University of Chicago Press, Chicago. At 286, 341.

[42] Ibid at 312,322.

[43] See Hicks, Supra Note 7.

[44] Faulkner, W.L. and Ory, H.W. (1976) Intrauterine Devices and Acute Pelvic Inflammatory Disease. Journal of the American Medical Association, 235, 1851-1853. http://dx.doi.org/10.1001/jama.1976.03260430021016

[45] Burkman, R.T. (1981) Association between Intrauterine Device and Pelvic Inflammatory Disease. Obstetrics and Gynecology, 57, 269-276.

[46] Cates Jr., W., op.cit., 1155-1159.

[47] Daling, J.R., Weiss, N.S., Metch, B.J., Chow, W.H., Soderstrom, R.M., Moore, D.E., Spadoni, L.R. and Stadel, B.V. (1985) Primary Tubal Infertility in Relation to the Use of an Intrauterine Device. The New England Journal of Medicine, 312, 937-941. http://dx.doi.org/10.1056/NEJM198504113121501

[48] Cramer, D.W., Schiff, I., Schoenbaum, S.C., Gibson, M., Belisle, S., Albrecht, B., et al. (1985) Tubal Infertility and the Intrauterine Device. The New England Journal of Medicine, 312, 941-947. http://dx.doi.org/10.1056/NEJM198504113121502

[49] Ory, H.W. (1978) A Review of the Association between Intrauterine Devices and Acute Pelvic Inflammatory Disease. Journal of Reproductive Medicine, 20, 200-204.

[50] Obituary “Hugh J. Davis,” New York Times, October 26, 1996.

[51] Trussell, J., Leveque, J.A., Koenig, J.D., London, R., Borden, S., Henneberry, J., LaGuardia, K.D., Stewart, F., Wilson, T.G., Sysocki, S., et al. (1995) The Economic Value of Contraception: A Comparison of 15 Methods. American Journal of Public Health, 85, 494-503. http://dx.doi.org/10.2105/AJPH.85.4.494

[52] Darney, P.D. (2001) Time to Pardon the IUD? The New England Journal of Medicine, 345, 608-610. http://dx.doi.org/10.1056/NEJM200108233450810

[53] K4Health, IUD Toolkit, Frequently Asked Questions, 2010. http://www.k4health.org/node/974\#5

[54] Ory, H.W. (1981) Ectopic Pregnancy and Intrauterine Contraceptive Devices: New Perspectives. The Women’s Health Study. Obstetrics and Gynecology, 57, 137-144.

[55] Sivin, I. (1999) Dose- and Age-Dependent Ectopic Pregnancy Risks with Intrauterine Contraception. Obstetrics and Gynecology, 78, 291-298.

[56] Anonymous (1990) The TCu380A, TCu220C, Multiload 250 and Nova T IUDS at 3,5 and 7 Years of Use-Results from Three Randomized Multicentre Trials. World Health Organization, Special Programme of Research, Development and Research Training in Human Reproduction: Task Force on the Safety and Efficacy of Fertility Regulating Methods. Contraception, 42, 141-158. http://dx.doi.org/10.1016/0010-7824(90)90098-G

[57] Lee, N.C., Rubin, G.L. and Borucki, R. (1988) The Intrauterine Device and Pelvic Inflammatory Disease Revisited: New Results from the Women's Health Study. Obstetrics and Gynecology, 72, 1-6.

[58] Grimes, D.A. (2000) Intrauterine Device and Upper-Genital-Tract Infection. The Lancet, 356, 1013-1019. 
http://dx.doi.org/10.1016/S0140-6736(00)02699-4

[59] Sorbye, I.K., Jerve, F. and Staff, A.C. (2005) Reduction in Hospitalized Women with Pelvic Inflammatory Disease in Oslo over the Past Decade. Acta Obstetricia et Gynecologica Scandinavica, 84, 290-296. http://dx.doi.org/10.1080/j.0001-6349.2005.00509.x

[60] Odugbemi, T., McEntegart, M. and Hafiz, S. (1978) Effects of Various Divalent Cations on the Survival of Nesisseria Gonorhoeae in Liquid Media. British Journal of Venereal Disease, 54, 239-242.

[61] Mehanna, M.T.R., Rizk, M.A., Ramadan, M. and Schachter, J. (1994) Chlamydia Serologic Characteristics among Intrauterine Contraceptive Device Users: Does Copper Inhibit Chlamydial Infection in the Female Genital Tract? American Journal of Obstetrics \& Gynecology, 171, 691-693. http://dx.doi.org/10.1016/0002-9378(94)90083-3

[62] Toivonen, J., Luukkainen, T. and Allonen, H. (1991) Protective Effect of Intrauterine Release of Levonorgestrel on Pelvic Infection: Three Years' Comparative Experience of Levonorgestrel- and Copper Releasing Intrauterine Devices. Obstetrics and Gynecology, 77, 261-264. http://dx.doi.org/10.1097/00006250-199102000-00019

[63] Ebi, K.L., Piziali, R.L., Rosenberg, M. and Wachob, H.F. (1996) Evidence against Tailstrings Increasing the Rate of Pelvic Inflammatory Disease among IUD Users. Contraception, 53, 25-32. http://dx.doi.org/10.1016/0010-7824(95)00253-7

[64] Skjeldestad, F.E. (2008) The Impact of Intrauterine Devices on Subsequent Fertility. Current Opinion in Obstetrics and Gynecology, 20, 275-280. http://dx.doi.org/10.1097/GCO.0b013e3282fe7427

[65] Hubacher, D., Lara-Ricalde, R., Taylor, D.J., Guerra-Infante, F. and Guzman-Rodriquez, R. (2001) Use of Copper Intrauterine Devices and the Risk of Tubal Infertility among Nullagravid Women. The New England Journal of Medicine, 345, 561-567. http://dx.doi.org/10.1056/NEJMoa010438

[66] Wilson, J.C. (1989) A Prospective New Zealand Study of Fertility after Removal of Copper Intrauterine Contraceptive Devices for Conception and Because of Complications: A Four-Year Study. American Journal of Obstetrics and Gynecology, 160, 391-396. http://dx.doi.org/10.1016/0002-9378(89)90455-9

[67] Hov, G.G., Skjeldestad, F.E. and Hilstad, T. (2007) Use of IUD and Subsequent Fertility-Follow-Up after Participation in a Randomized Clinical Trial. Contraception, 75, 88-92. http://dx.doi.org/10.1016/j.contraception.2006.09.010

[68] Meyers, D., Wolff, T., Gregory, K., Marion, L., Moyer, V., Nelson, H., Petitti, D. and Sawaya, G.F. (2010) US Preventive Services Task Force Recommendations for STI Screening. http://www.ahrq.gov/Clinic/uspstf08/methods/stinfections.htm

[69] Geisler, W.M., Chow, J.M., Schachter, J. and McCormack, W.M. (2007) Pelvic Examination Findings and Chlamydia Trachomatis Infection in Asymptomatic Young Women Screened with a Nucleic Acid Amplification Test. Sexually Transmitted Diseases, 34, 335-338.

[70] American College of Obstetricians and Gynecologists Committee (2007) Intrauterine Device and Adolescents, American College of Obstetricians and Gynecologists Committee Opinion No. 392. Obstetrics and Gynecology, 110, 14931495.

[71] American College of Obstetricians and Gynecologists Committee (2005) Intrauterine Device, American College of Obstetricians and Gynecologists Committee on Practice Bulletins-Gynecology No. 59. Obstetrics and Gynecology, 105, 223-232.

[72] World Health Organization (2004) Intrauterine Devices. In: Medical Eligibility Criteria for Contraceptive Use, 3rd Edition, WHO, Geneva, 1-17. http://www.who.int/reproductive-health/publications/mec/7 iud.pdf

[73] Patient Package Insert (2010) Paragard T380 Intrauterine Copper Contraceptive. Duramed Pharmaceutical, Inc., Subsidiary of Barr Pharmaceuticals, New York. 
Scientific Research Publishing (SCIRP) is one of the largest Open Access journal publishers. It is currently publishing more than 200 open access, online, peer-reviewed journals covering a wide range of academic disciplines. SCIRP serves the worldwide academic communities and contributes to the progress and application of science with its publication.

Other selected journals from SCIRP are listed as below. Submit your manuscript to us via either submit@scirp.org or Online Submission Portal.
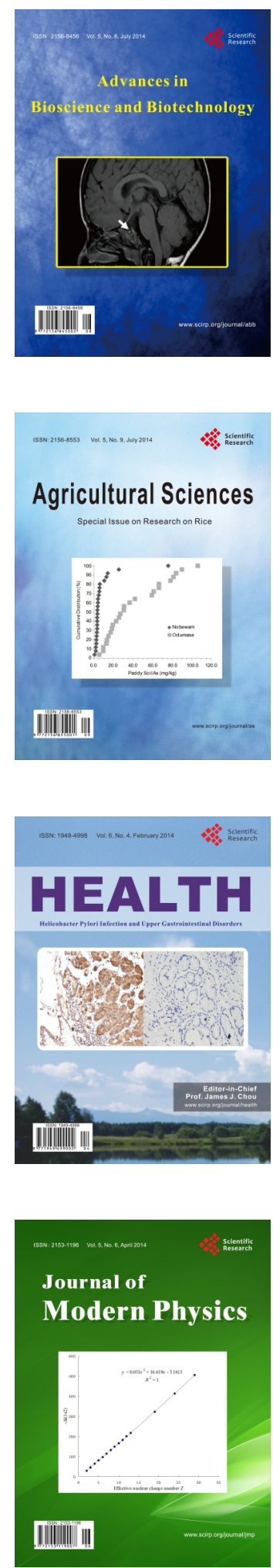
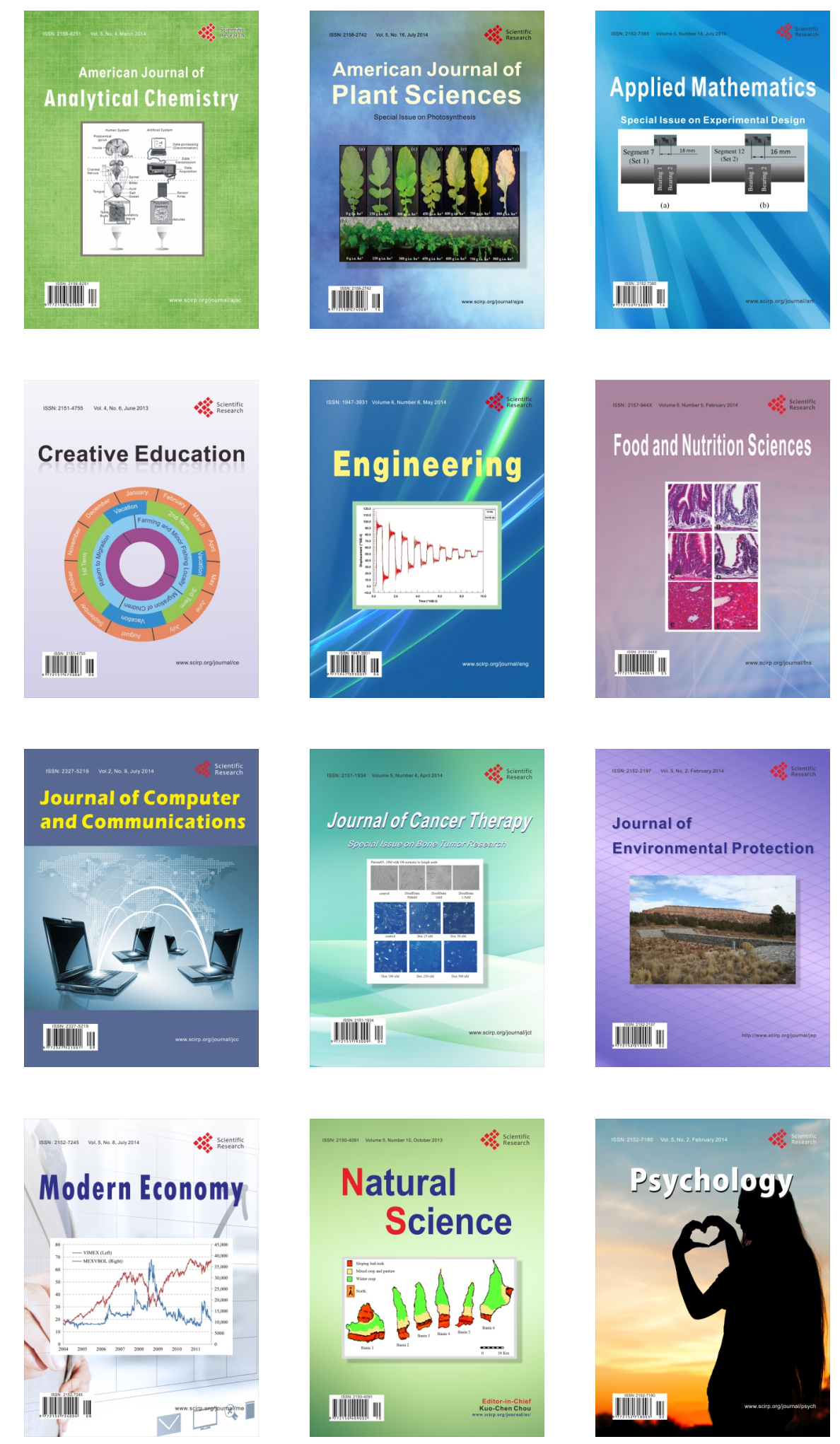